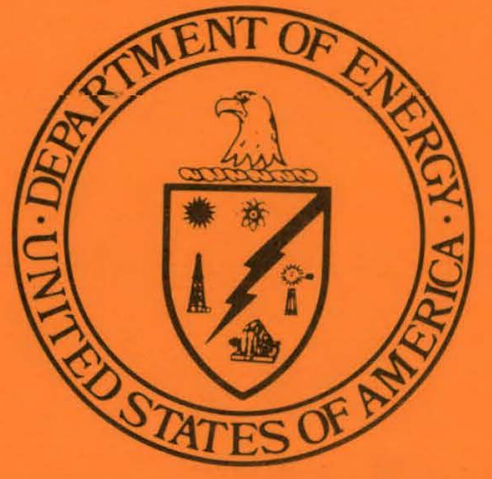

$\mathrm{DOE} / \mathrm{MC} / 19210-1466$

(DE83017041)

\title{
COMPUTED TOMOGRAPHY OF COALS
}

Quarterly Technical Progress Report No. 1

For The Period 8/16/82 to $11 / 28 / 82$

By

D. H. Maylotte, et. al.

September 1983

Work Performed Under Contract No. : DE-AC21-82MC19210

For

U. S. Department of Energy

Morgantown Energy Technology Center

Morgantown, WV

By

General Electric Corp.

Research and Development Center

Schenectady, NY 


\section{DISCLAIMER}

This report was prepared as an account of work sponsored by an agency of the United States Government. Neither the United States Government nor any agency Thereof, nor any of their employees, makes any warranty, express or implied, or assumes any legal liability or responsibility for the accuracy, completeness, or usefulness of any information, apparatus, product, or process disclosed, or represents that its use would not infringe privately owned rights. Reference herein to any specific commercial product, process, or service by trade name, trademark, manufacturer, or otherwise does not necessarily constitute or imply its endorsement, recommendation, or favoring by the United States Government or any agency thereof. The views and opinions of authors expressed herein do not necessarily state or reflect those of the United States Government or any agency thereof. 


\section{DISCLAIMER}

Portions of this document may be illegible in electronic image products. Images are produced from the best available original document. 


\section{DISCLAIMER}

This report was prepared as an account of work sponsored by an agency of the United States Government. Neither the United States Government nor any agency thereof, nor any of their employees, makes any warranty, express or implied, or assumes any legal liability or responsibility for the accuracy, completeness, or usefulness of any information, apparatus, product, or process disclosed, or represents that its use would not infringe privately owned rights. Reference herein to any specitic commercial product, process, or service by trade name, trantemark. maunfacturer, or otherwise does nnt necessarily constitute or imply its endorsement, recommendation, or favoring by the United States Government or any agency thereof. The views and opinions of authors expressed herein do not necessarily state or reflect those of the United States Government or any agency thereof.

This repnrt has been reproduced directly from the best available copy.

Available from the National Technical Information Service, U. S. Department of Commerce, Springfield, Virginia 22161.

Price: Printed Copy A02

Microfiche A01

Codes are used for pricing all publications. The code is determined by the number of pages in the publication. Information pertaining to the pricing codes can be found in the current issues of the following publications, which are generally available in most libraries: Energy Research Abstracts (ERA); Government Reports Announcements and Index (GRA and I); Scientific and Technical Abstract Reports (STAR); and publication NTIS-PR-360 available from NTIS at the above address. 


\title{
COMPUTED TOMOGRAPHY OF COALS
}

\author{
Quarterly Technical Progress Report No. 1
}

For The Period $8 / 16 / 82$ to $11 / 28 / 82$

\author{
By \\ D. H. Maylotte, P. G. Kosky, \\ C. L. Spiro and E. J. Lamby
}

September 1983

Work Performed Under Contract No. : DE-AC21-82MC19210

\author{
For \\ U. S. Department of Energy \\ Morgantown Energy Technology Center \\ P.O. Box 880 \\ Morgantown, WV 26505 \\ By \\ General Electric Corporate Research \\ and Development Center \\ P.O. Box 8 \\ Schenectady, NY 12301
}


TABLE OF CONTENTS

$\underline{\text { Page }}$

I. Introduction ................. 1

II. Experimental Program and Results ............... 1

IIT. References................... 3

IV. Appendix A . . . . . . . . . . . . . . . . . . . 9 
TART.F.S

$\underline{\text { Page }}$

1. Coal Samples Collected . . . . . . . . . . . . . . . . . . . . . . 4 


\section{FIGURES}

$\underline{\text { Page }}$

1. C'I Picture of Pittsburgh Coal in Air . . . . . . . . . . . . . . . . 5

2. Schematic Diagram of Coal Porosity Apparatus . . . . . . . . . . . . 6

3. Schematic Diagram of Gas Handling System . . . . . . . . . . . . . . 7

4. Schemat1c Diagran ul Data Collection Equfpmenl (Appendix A) . . . : 8 
1. Intronduction

The purpose of this contract is to examine the utility and advantages of $x$-ray computed tomography (CT) for investigating the structure within coal and the changes that occur in these structures during such processes as combustion and gasification. The CT technique is noninvasive and nondestructive. It can produce interior views of the coal and, with a data acquisition time of ca. 9 seconds, can be used for following many coal processes in real time.

This is the first in-depth study of the application of the $x$-ray tomography technique to the problems in coal utilization, and consequently, considerable time will be spent in the early stages of this contract in examining CT pictures of coal and relating them to more conventional petrographic and mineral analyses. This phase of the work is being undertaken in Task 1 of the contract and is reported for this period. Building on this foundation, the succeeding tasks will follow changes in the coal structure during reaction.

The first series of CT experiments is scheduled to take place on December 11-13, 1982, at the General Electric Company, Medical Systems Operation, Milwaukee, Wisconsin.

II. Experimental Procedures and Results

Task 1.1-- Coal Structure and Composition

A range of coals had to be assembled for the purposes of this task. To this end, coals were collected by us from the seams given in Table 1. The samples were collected at freshly opened faces and were taken from a vertical channel cut. Photographs were taken of the seam at the site where the samples were taken.

Because the CT experiments require large pieces $(\geq 2 \mathrm{~cm}$ ) emphasis was placed on collecting large intact pieces from the coal face.

The samples are being stored in sealed glass jars under nitrogen. The choice of seam was based upon a combination of its economic importance and petrographic interest.

Samples of Illinois No. 6 will be obtained from the University of Southern Illinois and samples of Beulah Zap lignite from Pennsylvania State University. A full characterization of these coals is planned the supplying institutions. This should prove very useful in interpreting the CT pictures.

Other coal samples will be drawn from the existing coal bank at General Electric or, if necessary, mined by us.

Large pieces (ca. $5 \times 5 \times 15 \mathrm{~cm}$ ) have been selected and potted in polyester resin for examination on the $\mathrm{CT}$ machine. The polyester will act as a support when the coal is sectioned for petrographic examination and also it will minimize edge errors in the CT examinations. The reconstruction algorithm for the CT image tends to overshoot when there are sudden 
density changes. This can be seen in the light rim around the coal in Figure 1. This coal was imaged in air and the overshoot caused by the sudden density change from air to solid coal.

We expect to have approximately 50 samples of coal ranging in rank from lignite to anthracite ready for $\mathrm{CT}$ examination.

Task $1.2--$ Coal Porosity

In this subtask, the early stages of diffusion of an x-ray opaque gas, e.g., xenon, will be used to examine the porosity and connectivity within coals.

Three sallples of Illinois No. 6 coal have been selected for the first test. All three pieces are approximately $3 \times 3 \times 10 \mathrm{~cm}$ and were cut from the same lump of coal. Two of the pieces were cut with the bedding planes parallel to the long axis, and one piece was cut with the bedding planes perpendicular to the long axis.

The coals have been potted in an epoxy resin (Dexter Hysol resin RE 2039 with HE 3495 hardener), which cures at $65^{\circ} \mathrm{C}$ and when hard can be used at temperatures in excess of $110^{\circ} \mathrm{C}$. At the low curing temperature, there should be no damage to the coal structure (1).

The coals will be used with their ambient moisture content. for the first series of experiments. Later experiments will examine diffusion into the samples after prolonged evacuation or at elevated temperatures. After these experiments have been completed, the coals will be sectioned for petrographic examination.

The apparatus for the diffusion experiment has been completed.' Each coal sample is to be mounted in an individual plastic tube in such a way that a pressure differential can be maintained across the coal (Figure 2). Three of these tubes have been mounted on a platform that can move in and out of the $x$-ray fan of the CT machine under computepr rontrnt. Farh apparatus is equipped with transducers for pressure measurements and thermocouples for temperature measurements. The data acquisition system is hased unnn an HP 85 desk-top computer and ie diccucced further in Áppendix $A$.

The experiments discussed above will examine the early stages of diffusion into coals. The ultimate porosity of coal will be examined in another series of experiments. Samples for these experiments have been prepared by cutting coal pieces approximately $3 \times 310 \mathrm{~cm}$ and potting them in polyester resin. The samples cover the range from lignite to bituminous. These samples will first of all be examined by CT in their ambient state, then after extended evacuation, and finally after extended exposure to xenon. 
REFERENCES

1. P. L: Walker, Jr., and O. P. Mahajan, in "Analytical Methods for Coal and Coal Products," ed. C. Karr, Jr., Vol. 1, Academic Press, 1978. 
TABLE 1

Coal Samples Collected

\begin{tabular}{|c|c|c|}
\hline ID & Rank & Comments \\
\hline C268 & Bituminous & $\begin{array}{l}\text { Lower Kittanning (nonmarine). The sample is ca. } \\
40 \text { pounds and was mined at the Dean Mine, Cambria } \\
\text { County of the Bender Coal Company, Carroltown, } \\
\text { Pennsylvania. The sample was mined on November } 3 \text {, } \\
1982 \text {. }\end{array}$ \\
\hline
\end{tabular}

C267

C269 - C271 Bituminous

$\mathrm{L}-\mathrm{C} 289$

$\mathrm{U}-\mathrm{C} 290$

C240- C248

C291

$\mathrm{C} 249-\mathrm{C} 254$

$\mathrm{C} 272$ - C273

$\mathrm{C} 225-\mathrm{C} 261$

(WE)

C.262 - C.6.66

(PEA)

$\mathrm{C} 274-\mathrm{C} 278$

$\mathrm{C} 279-\mathrm{C} 282$

$\mathrm{C} 283-\mathrm{C} 288$
Subbituminous

Subbituminous

Bituminous

Bituminous

Subbituminous

Subbituminous

Subbituminous

Subbituminous
Lower Kittanning (marine). The sample is ca. 20 pounds and was mined at Mine No. 9-50, 54 of the Stahlman Coal Company, Jefferson, Pennsylvania. l'his sample was mined on November 4, 1982.

Ohio No. 6 (Middle Kittanning). This sample is 30-50 pounds and was mined at the Coonville Mine, Mason Company, of the Valley Coal Company. The sample was collected on November 5, 1982.

Small samples (ca. 5 pounds each) were also collected at the Upper Mercer A and Lower Mercer A seams during the visit to the Bender Coal Company.

Upper Wyodak. The sample was ca. 40 pounds and was mined on November 2, 1982, at the Wyodak Mine of the Wyodak Resources Development Corporation, Gillette, Wyoming.

Lower Wyodak. This sample is about the same size as the above sample and was collected during the same visit.

Rosebud. Two samples of this seam were collected on November 3, 1982. The first was from the Rosebud Mine of the Western Energy Company and the second from the Big Sky Mine of the Peabody Coal Company. Both mines are situated near Colstrip, Montana. Each sample was ca. 40 pounds.

Dietz No. 1 Upper. This sample is ca. 35 pounds and was collected from the East Mine of the Decker Coal Company, Decker, Montana, on November 4, 1982 .

Dietz No. 1 Lower. The sample is about the same size as the above sample and was collected during the same visit.

Dietz No. 2. The sample is ca. 35 pounds and was collected during the same visit as the above s ample. 


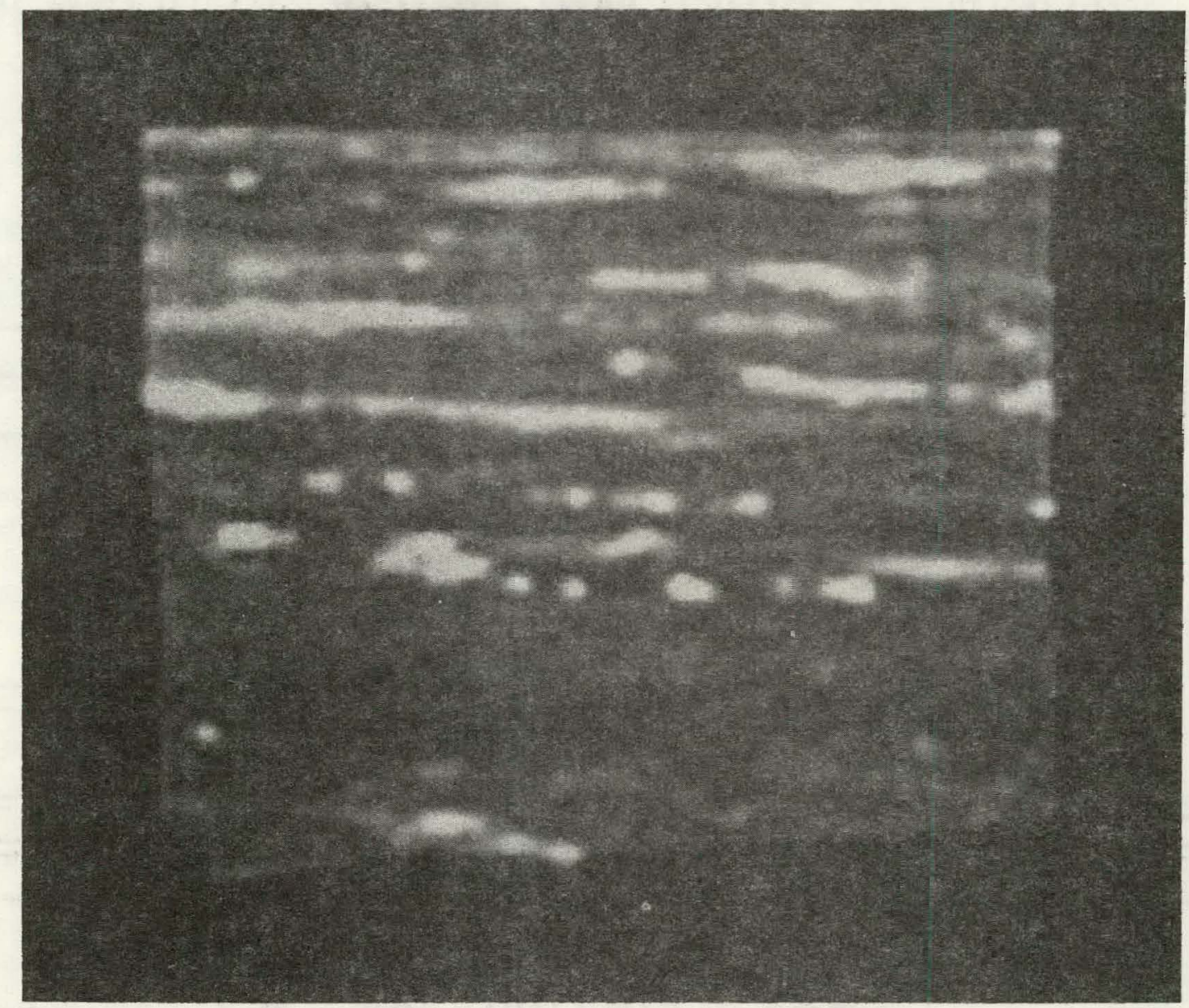

Figure 1. Computed Tomography Picture of Coal 
- LOW

PRESSURE

SIDE

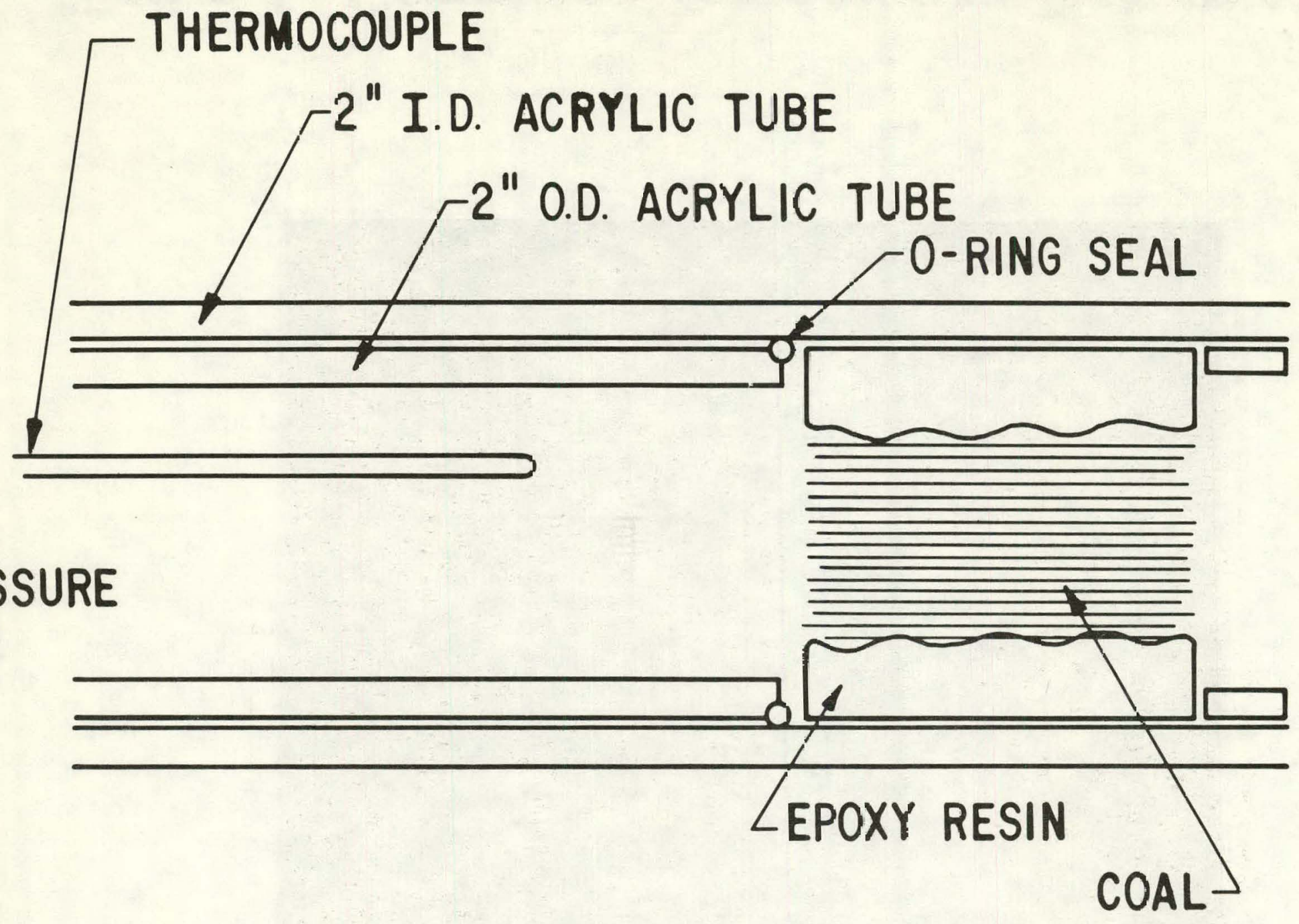

FIGURE 2
HIGH PRESSURE

ACRYLIC SPACER

SCHEMATIC OF XENON DIFFUSION APPARATUS 


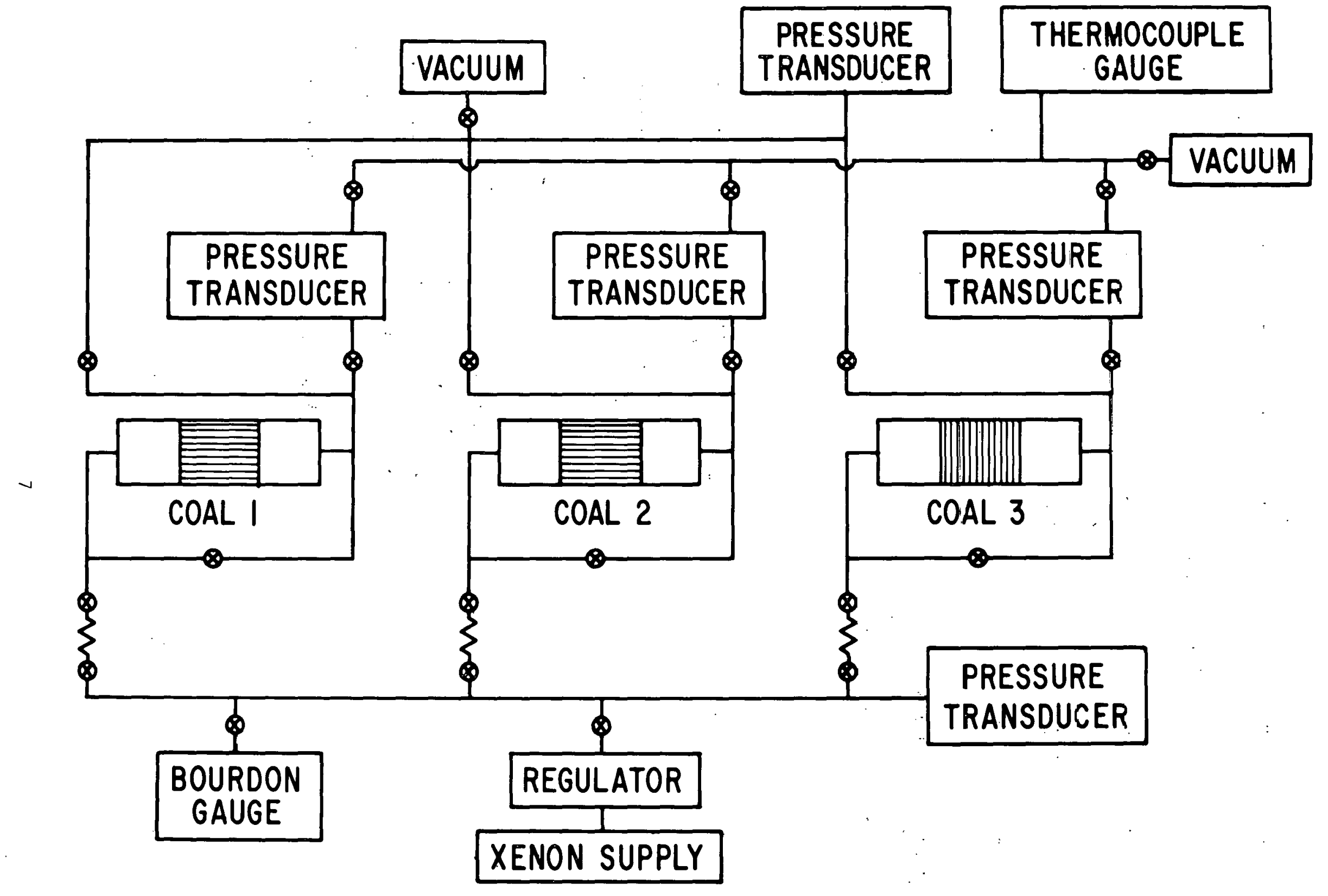

FIGURE 3

SCHEMATIC OF GAS CONNECTIONS IN THE XENON DIFFUSION APPARATUS 


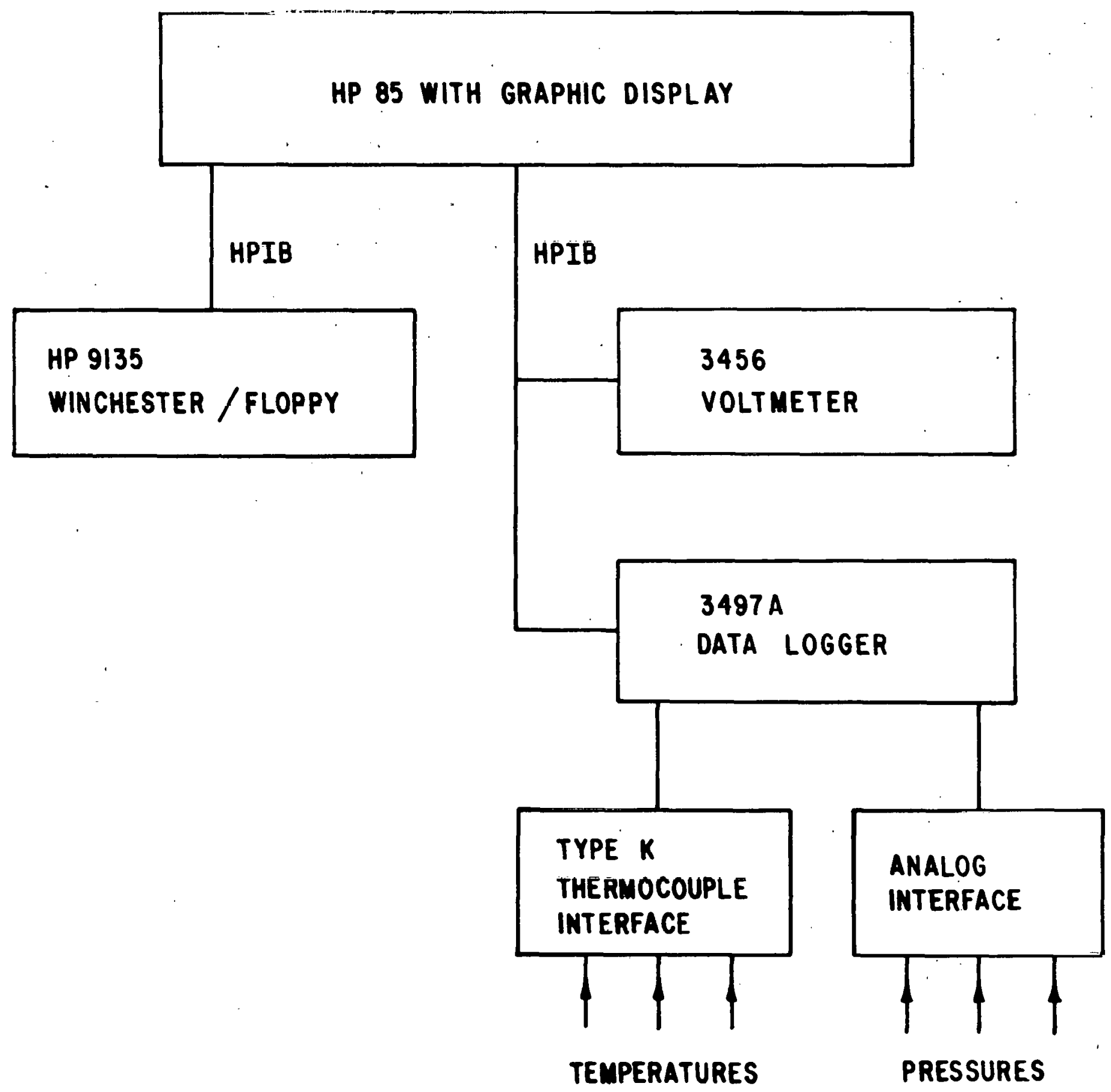

FIGURE 4 DATA ACQUISITION SYSTEM 


\section{Appendix A}

The Hewlett-Packard data acquisition system is shown schematically in Figure 4. Analog signals from pressure transducers and Type $K$ thermocouples are attached to the interface cards for the $3497 \mathrm{~A}$ data logger. A Basic language computer program has been written to repetitively scan up to 20 channels of temperature data and up to 20 channels of analog data and store the data on the Winchester hard disc. Although the "Fast Handshake Mode" is used for data transfer, high speed is not a requirement of this data acquisition task. The time interval between scans is under operator control. We expect that in practice each channel will be examined about every 30 seconds.

Upon starting the data acquisition, the values from one channel can be chosen for display using the graphic capability of the HP 85. In addition, a "scroll" mode is available that displays the values from all the attached channels during the last data scan. These scrolling and graphing functions are independent of the data acquisition function. 